Elsevier required licence: (c) $<2017>$. This manuscript version is made available under the CC-BY-NC-ND 4.0 license http://creativecommons.org/licenses/bync-nd/4.0/ 


\title{
A Square Deal? Mining Costs, Mining Royalties and Local Government in New South Wales, Australia
}

\begin{abstract}
Mining operations are often controversial since they can impose significant external costs on the local municipalities and local inhabitants. Under current legislative arrangements in New South Wales (NSW), Australia, local governments are constrained from recouping costs directly from mines by means of increased property taxes on mines due to state-wide limitations on tax increases - known colloquially as the 'rate-cap'. Moreover, mining royalties are paid directly to the NSW government and not to affected councils. In this paper, set against the background of mining activities in NSW, we estimate the magnitude of costs imposed by mining operations on rural and regional local authorities. We then offer alternative public policy solutions which would enable affected municipalities to recoup some or all of the cost burden placed on them by mining operations in their respective local government areas.
\end{abstract}

Keywords: mining costs; local government; municipal revenue; property taxes

\section{Introduction}

Australia is blessed by considerable mineral wealth and it has become a major exporter of both energy commodities, especially coal, liquefied natural gas and uranium, as well as minerals, notably iron ore, gold and base metals (ABARES, 2016). Under the Australian Constitution, mineral reserves are owned by state and territory governments, which assign both exploration and production rights to mining companies, and then levy resource taxes or royalties on these companies (Henry et al, 2010; Blackwell and Dollery, 2013). A substantial literature exists on the taxation of minerals in Australia (see, for example, Ergas, Harrison and Pincus, 2010; Ergas and Pincus, 2014; Freebairn, 2012; 2015; Garnaut, 2010; and Hogan, 2012), which mostly focuses on the evaluation of existing taxes and developing improved methods of taxation. One strand considers differences between the regulatory regimes of the different states and territories (Cronshaw and Grafton, 2016), which can affect the impact of mining. ${ }^{1}$

\footnotetext{
${ }^{1}$ Though not the main focus of this article, negative mining impacts can be moderated through a Social License to Operate (SLO), a social contract to mine with at least the implied approval of the local community, whether this be at local, regional, state, national or international spatial scales
} 
A number of scholars, including Battellino (2010) and Robson (2015), have considered the economic, environmental and social effects of the recent Australian mining boom. Although much of the scholarly literature directed at the mining boom has focused on its macroeconomic impact (see, for instance, McKissack, Chang, Ewing and Rahman, 2008; Downes, Hanslow and Tulip, 2014; Knop and Vespignani, 2014; Bashar, 2015; Fleming, Measham and Paredes, 2015; Fleming and Measham, 2015), some work has also examined the impact of the boom at the regional and local levels. For example, Perry and Rowe (2015) examined the effects of 'fly-in fly-out' workers on local communities, Blackwell and Dollery (2014) considered the effects of mining expenditure on local economies, Fleming and Measham (2014) investigated the local job multipliers attendant upon mining, Blackwell, Fischer, McFarlane and Dollery (2015) empirically analysed employment leakage by Local Government Area (LGA) in the Northern Territory, Petrova and Marinova (2013) evaluated the social impact of mining, and Garnett and Lewis (2007) studied demographic and employment shifts contingent upon mining.

In addition, some scholars have considered the impact of mining on local government in regional and remote Australia. For instance, Cheshire, Everingham and Lawrence (2014) examined the challenges posed by mining. Similarly, Loechel, Hodgkinson and Moffat (2013) studied climate change mitigation at the local level. However, to date no work has examined empirically the financial impact of mining operations on local authorities responsible for their LGAs in terms of revenue and expenditure.

In this paper we seek to address this gap in the literature by investigating municipal operational expenses contingent on mining in New South Wales (NSW) local government over the period 2012 to 2015 inclusive. We also offer alternative public policy proposals which would allow local authorities negatively affected by mining operations to recoup some or all of the cost burden placed on them by mining in their respective local government areas. Given that the NSW Government (i.e. the government of the state of NSW) has the exclusive power to levy taxes on mining, we are thus concerned with the fiscal relationship between the NSW and its local government system.

The paper is divided into four main areas. Section 2 provides a brief synoptic review of both the NSW local government system as well as the mining industry in NSW by way of institutional background. Section 3 outlines the data and empirical methodology employed in the paper and the results of the empirical estimations are considered in section 4. The paper ends in section 5 with a discussion of

and with varying degrees of formal and informal representation (Fordham, Robinson and Blackwell, 2017). 
the policy implications of the analysis

\section{Institutional Background}

\subsection{New South Wales Local Government}

Under the Australian Constitution, Australia is a federal state with a national government, has six states and two territories. The ownership of mineral resources under the surface resides with state and territory governments, including the capacity to impose taxes on the exploitation of these resources. Apart from the Australian Capital Territory, containing the national capital city Canberra, each of the seven states and territories has its own local government system. In terms of the Constitution, each local government system falls under its own state government. In general, state governments exercise decisive powers over local government, including the ability to abolish or forcibly merge local councils.

Prior to its recent structural reform through forced municipal mergers ${ }^{2}$, NSW local government compromised 152 'general purpose councils' (referred to as Local Government Areas for statistical purposes), 12 'special purpose councils' and the NSW Aboriginal Land Council. NSW local councils are overseen by the NSW Office of Local Government, the NSW Independent Pricing and Regulatory Tribunal (IPART), NSW Local Government Grants Commission and various other ancillary bodies falling under the NSW Local Government Act (1993). Relative to most other advanced nations, Australian local government systems, including NSW, provide a limited range of functions largely focused on 'services to property'. In particular, NSW councils deliver local infrastructure, including local roads, and local services, like sewage and solid waste disposal, with some regional councils operating local water utilities. NSW local government is financed through a combination of property taxes ('rates'), fees and charges, intergovernmental grants, developer charges and some other minor sources of income. Its financial latitude is severely constrained by a longstanding rate-capping policy by the NSW Government which imposes upper limits on aggregate increases in property taxes. Local councils fall under elected councillors and (usually) indirectly elected mayors, who face four-year

\footnotetext{
${ }^{2}$ The NSW structural reforms were forced amalgamations predicated on financial sustainability (and associated metrics). Nineteen new councils were created through forced amalgamation in May 2016, however, a number of other planned amalgamations were eventually aborted due to successful Court action. Some of the councils which were merged to enhance financial sustainability had extensive mining activity (e.g. Gloucester, NSW) which means that any uncompensated burden imposed as a result of hosting mining operations may have contributed to the council ceasing to exist as an stand-alone entity.
} 
electoral periods. The operational side of councils is run by a general manager overseeing a local bureaucracy.

\subsection{Mining and Mine Revenue in New South Wales}

Mining in NSW began with the discovery of coal in Newcastle in the 1790s and spread to the Illawara region with its high grade coking coal in 1848 (NSW Minerals Council, 2013a). From the late 1800's onwards, Newcastle and Wollongong developed into fully-fledged ports, exporting minerals from inland towns as far as Broken Hill (NSW Mineral Council, 2013a). Coal fields today run through NSW to the Queensland border.

In 1851, gold was discovered near Orange (NSW Minerals Council, 2013a). Caldia Hill was the first gold and copper mining operation in 1870 and it continues as one of the largest gold mines in Australia (NSW Minerals Council, 2013a). Regional towns whose development centred on mining include Newcastle, Broken Hill, Wollongong, Cessnock, Mussellbrook, Singleton, Lithgow, Orange, Gunnedah and Cobar. Figure 1 provides a spatial perspective on contemporary mining in NSW by numbers of mines and mineral types:

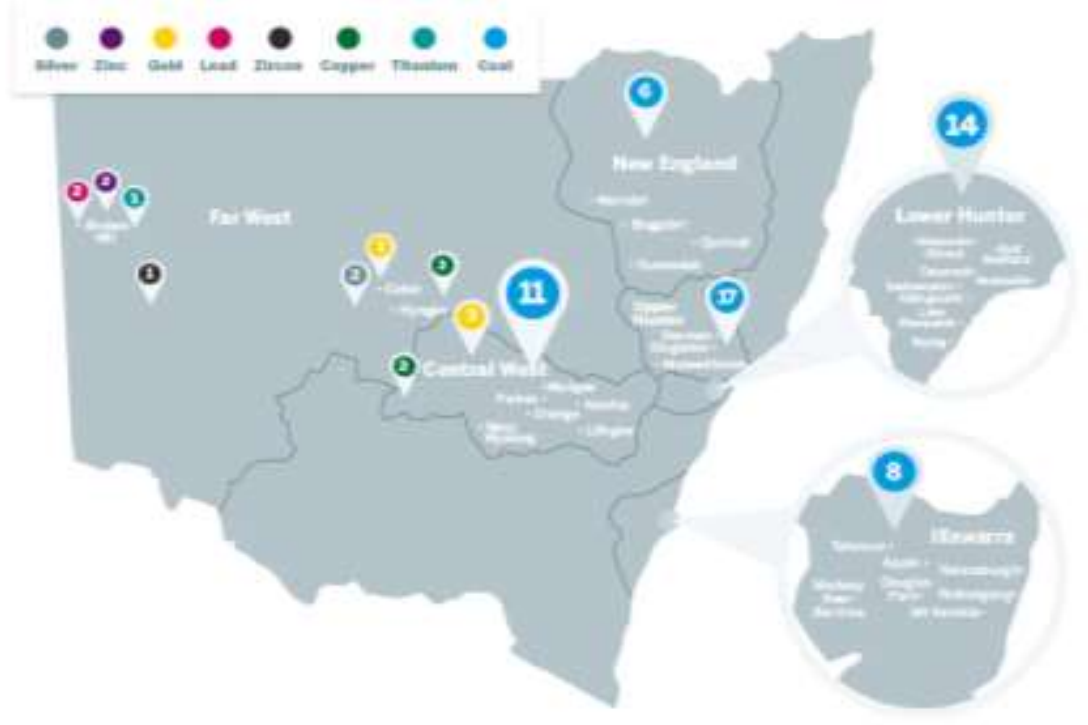

Figure 1: NSW Mine Numbers and Mineral Types. Source: NSW Minerals Council (2013b). 


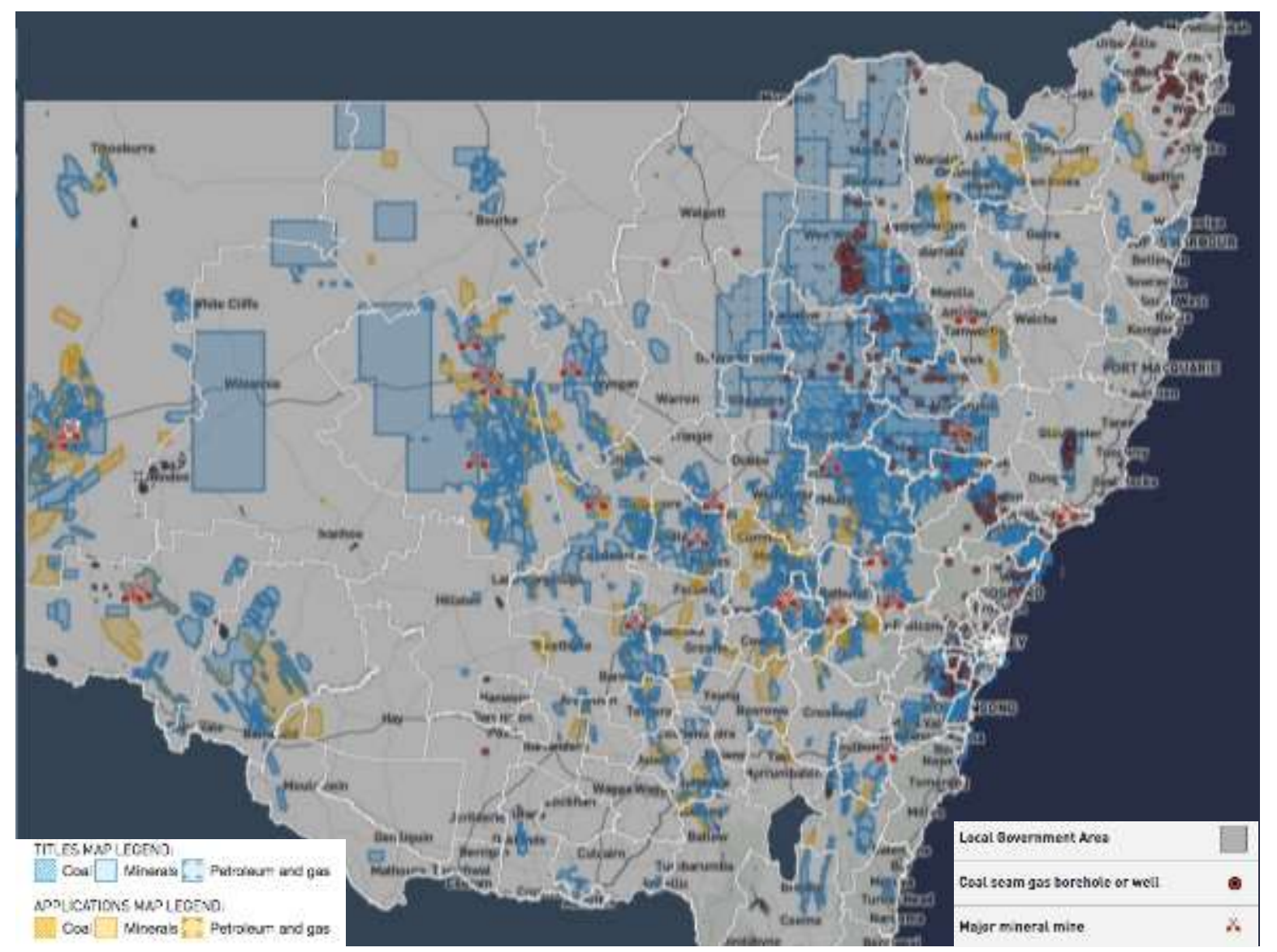

Figure 2: Major mines, mining titles and gas wells with LGA boundaries in NSW. Source: Derived from Common Ground (2017)

The NSW mining industry is economically important in its own right. For instance, Newcastle is currently the world's largest coal export port (NSW Minerals Council, 2013a). In aggregate, NSW mining production in 2011-12 generated \$27billion (Australian dollars; Office of Chief Economist, 2014, p. 23). Figure 2 shows the overlap of mining with local government authority (LGA) boundaries as well as a broad indication of LGA mining assessment activity ('assessment' is the term used in Australia to describe the notice of local government taxation liability - as such, assessments reflect the number of properties, in this case mining properties, in a given LGA).

NSW mining is significant in the overall national context. Table 1 contains Australian mining royalties by state for 2015-16. NSW accrues some $\$ 1.2$ billion (or 15 percent of total royalties in Australia at almost $\$ 8$ billion). NSW royalties are predominantly derived from coal production, in common with Queensland, but in contrast to Western Australia where iron ore is the major contributor.

Table 1: State Royalty Revenues, Australia, 2015-16 


\begin{tabular}{|c|c|c|}
\hline State/territory & Royalty revenue (\$m) & Percent of Total (\%) \\
\hline Western Australia ${ }^{a}$ & 4,134 & $52 \%$ \\
\hline Queensland ${ }^{\mathrm{b}}$ & 2,173 & $27 \%$ \\
\hline New South Wales ${ }^{c}$ & 1,187 & $15 \%$ \\
\hline Northern Territory ${ }^{d}$ & 194 & $2 \%$ \\
\hline South Australia ${ }^{\mathrm{e}}$ & 222 & $3 \%$ \\
\hline Tasmania $^{f}$ & 28 & $0.4 \%$ \\
\hline Victoria $^{g}$ & 48 & $0.6 \%$ \\
\hline Australian Capital Territory ${ }^{\mathrm{h}}$ & 0 & $0 \%$ \\
\hline Total & 7,986 & $100 \%$ \\
\hline
\end{tabular}

Sources and notes: State or territory government budgets 2016-17: a. Government of Western Australia, 2016, calculated from p. 89; b. Queensland Treasury, 2016, p. 100; c. NSW Government, 2016, p. A4-6; d. NT Government, 2016, p. 56; e. SA Government, 2016, p. 53; f. Tasmanian Government, 2016, p. 98; g. Victorian Government, 2016, p. 164; h. ACT Government, 2016 (not in budget).

Table 2 shows that NSW mining accounts for 18 percent of all Australian mining employment at 41,000 people. NSW royalties account for 15 percent of total Australian royalties and NSW accounted for 28 percent of the gross value of mineral production in Australia in 2011-12.

Under constitutional law, the NSW Government owns all mineral resources in NSW (NSW Mineral Council, 2013c). Royalties from mining enter consolidated revenue and are used to fund general outlays, such as education and health, which are expended predominantly in metropolitan, not rural areas. There is thus a mismatch between where the resource is extracted and where its royalties expended, sometimes termed the 'resource-return mismatch'.

In NSW, a Resources Regulator is responsible for the enforcement of the Mining Act as well as regulating safety and health in NSW mining (NSW Department of Industry: Resources and Energy, 2017a). By contrast, the Environment and Protection Authority regulates coal seam gas exploration and production activities, with the exception of work health and safety matters (O'Kane, 2014).

Table 2: Selected Economic Measures for NSW and Australia

\begin{tabular}{lcccc}
\hline Measure & NSW & Australian total & NSW/Australia (\%) & Relevant year \\
\hline Total Employment (000's) a & 3,809 & 12,004 & $32 \%$ & Nov 2016
\end{tabular}




\begin{tabular}{|c|c|c|c|c|}
\hline Mining Employment (000's) a & 41 & 232 & $18 \%$ & Nov 2016 \\
\hline Gross State Product (\$ billion) c & 531 & 1,662 & $32 \%$ & $2015-16$ \\
\hline Mineral Production ( $\$$ billion) $d$ & 27 & 202 & $13 \%$ & 2011-12 \\
\hline State Taxes ( $\$$ billion) e & 26 & 93 & $28 \%$ & 2015-16 (Vic 2016-17) \\
\hline
\end{tabular}

In all Australian states and territories, rights to access land, water and minerals are separated, thereby providing the benefits of sequential and multiple use. However, unintended consequences may result, such as water table pollution or insufficient funds to rehabilitate closed mines. These deleterious unintended consequences are typically born by those communities where a given mine is located. This matching of resource extraction and bearing its unintended consequences may be termed the 'resource-consequences match'. Taken together, the 'resourcereturns mismatch' and 'resource-consequences match' typically mean local non-metropolitan regions bear a considerable overlooked burden from mining activity. ${ }^{3}$ Under current fiscal arrangements, property taxes charged by local authorities in affected areas are employed for addressing this problem, as well as the impost of mining operations on local infrastructure, such as roads and bridges, in regional and rural areas. It is thus vital from a public policy perspective to determine empirically the fiscal burden borne by local authorities as a consequence of mining activities in their LGAs. This forms a major objective of this paper.

\section{Data and Empirical Methodology}

The model which we employed for this analysis was consistent with a large body of empirical work on Local Government expenditure functions (see, Drew, Kortt and Dollery, 2014 for a comprehensive review of this literature), and is given by:

$$
\mathbf{E}_{i t}=\alpha_{i}+\beta_{1} \mathbf{A}_{i t}+\beta_{2} \mathbf{X}_{i t}+\boldsymbol{\mu}_{i t} \quad \mathrm{t}=1 \ldots 4 \text { (equation 1) }
$$

\footnotetext{
${ }^{3}$ While the mining industry has developed the quasi-instrument of Social License to Operate (Fordham, Robinson and Blackwell, 2017) to mitigate any adverse impacts from mining, this 'contract' may involve direct and private royalty payments from the miner to the specific local community (Blackwell and Dollery, 2013). This implied license is a voluntary mechanism however, with no legal status and for some mining operations, does not exist in practice (e.g. see Lacey and Lamont, 2014).
} 
Where $\mathbf{E}$ is the operating expenditure per capita, $\mathbf{A}$ is a vector of assessment data (number of mining, business, farm and residential assessments - reflecting the number of each type of property - issued by the local government entity), $\mathbf{X}$ is a vector of control variables (i.e. average income of taxable individuals, proportion of individuals under 15 years of age, proportion of individuals over 65 years of age, proportion of individuals on a disability pension, proportion of individuals receiving Newstart welfare benefit, proportion of individuals identifying as Aboriginal or Torres Strait Islander, proportion of individuals speaking a language other than English at home, length of council sealed roads, length of council unsealed roads and population density) and $\boldsymbol{\mu}$ is an idiosyncratic error. The subscript it refers to the $i^{\text {th }}$ council entity and the $t^{\text {th }}$ year. Log transformations are standard practice where skewness occurs in regressands and regressors and only skewed variables were transformed (with the principal aim of ensuring normal residuals; transformations are noted in Table 3).

Table 3 provides details of the data employed to model the association between number of mining assessments and per capita operating expenditure in NSW local government areas. Operating expenditure was obtained directly from the audited financial statements for each of the 152 local governments for each of the four periods from 2011-12 to 2014-15 inclusive. Road length data was obtained from the relevant NSW Local Government Grants Commission (2012; 2013; 2014; 2015) reports. Number of assessments (by rating class - mining, business, farm and residential) was obtained from the Office of Local Government (2015) Time Series Data report. The Australian Bureau of Statistics (ABS) (2017) National Regional Profile was consulted for the remainder of the data. Moreover, it must be stressed that 2015 was the most recent year for which ABS data was available: it thus represented the upper temporal limit for the modelling undertaken in the paper. Local government areas of councils are a statistical boundary used by the Australian Bureau of Statistics. Table 3: Estimation Variables Employed (Figures are for Raw Data)

\begin{tabular}{|c|c|c|c|c|}
\hline Variable Name & Definition & $\begin{array}{l}\text { Mean } \\
\text { (standard } \\
\text { deviation) }\end{array}$ & Minimum & Maximum \\
\hline $\begin{array}{l}\text { Expenditure per } \\
\text { Capita }\end{array}$ & $\begin{array}{l}\text { Operating expenditure } \\
\text { divided by the resident } \\
\text { population in the local } \\
\text { government area. }\end{array}$ & $\begin{array}{l}1,795.133 \\
(1,083.713)\end{array}$ & 521.64 & $6,615.25$ \\
\hline
\end{tabular}




\begin{tabular}{|c|c|c|c|c|}
\hline Number of Mining & Number of mining & 3.035 & 0 & 58 \\
\hline Assessments & $\begin{array}{l}\text { assessments issued by the } \\
\text { local government entity. }\end{array}$ & $(12.062)$ & & \\
\hline Number of Farm & Number of farm & 765.077 & 0 & 4,243 \\
\hline Assessments & $\begin{array}{l}\text { assessments issued by the } \\
\text { local government entity, } \\
\text { divided by } 1000 \text {. }\end{array}$ & $(699.9)$ & & \\
\hline Number of Business & Number of business & $1,259.632$ & 47 & 18,285 \\
\hline Assessments & $\begin{array}{l}\text { assessments issued by the } \\
\text { local government entity. }\end{array}$ & $(1,795.265)$ & & \\
\hline Number of & Number of residential & $17,746.05$ & 283 & 102,783 \\
\hline Residential & assessments issued by the & $(20,949.36)$ & & \\
\hline Assessments & local government entity. & & & \\
\hline Average Wage & $\begin{array}{l}\text { Average wage of residents } \\
\text { living in the local } \\
\text { government area. }\end{array}$ & $\begin{array}{l}46,623.97 \\
(11,059.88)\end{array}$ & 32,408 & 123,235 \\
\hline $\begin{array}{l}\text { Individuals Under } 15 \\
\text { Years (\%) }\end{array}$ & $\begin{array}{l}\text { Proportion of individuals } \\
\text { under the age of } 15 .\end{array}$ & $\begin{array}{l}19.301 \\
(2.468)\end{array}$ & 7.1 & 28 \\
\hline $\begin{array}{l}\text { Individuals Over } 65 \\
\text { Years (\%) }\end{array}$ & $\begin{array}{l}\text { Proportion of individuals } \\
\text { over the age of } 65 \text {. }\end{array}$ & $\begin{array}{l}17.305 \\
(4.517)\end{array}$ & 7.8 & 32.9 \\
\hline $\begin{array}{l}\text { Disability Support } \\
\text { Pension }\end{array}$ & $\begin{array}{l}\text { Proportion of residents } \\
\text { receiving a disability support } \\
\text { pension. }\end{array}$ & $\begin{array}{l}1,760.23 \\
(2,276.806)\end{array}$ & 17 & 11,326 \\
\hline Newstart Allowance & $\begin{array}{l}\text { Proportion of residents } \\
\text { receiving Newstart } \\
\text { allowance. }\end{array}$ & $\begin{array}{l}1,269.696 \\
(1,794.323)\end{array}$ & 20 & 11,516 \\
\hline Aboriginal and & Proportion of residents & 5.330 & 0.1 & 59.1 \\
\hline Torres Strait & identifying as aboriginal or & (7.388) & & \\
\hline Islanders & Torres Strait Islander. & & & \\
\hline Non-english & Proportion of residents who & 11.038 & 0.9 & 71.0 \\
\hline
\end{tabular}


Speaking

Background

Sealed Roads

Unsealed Roads

Population Density speak a language other than

English at home.

Length of sealed (bitumen)

436.829

39

1,236

roads maintained by the

local government entity.

Length of unsealed (dirt)

0

roads maintained by the

local government area.

Resident population divided

772.433

0.0372

$7,974.333$

by the area of the local

government entity.

Fixed-effects panel regression was employed to examine the association between council expenditure and number of mining enterprises. Unlike other empirical methods, fixed-effects regression controls for time invariant variables: this means that the model is not sensitive to time invariant omitted variables bias and avoiding omitted variable bias is considered by many scholars to be the most important attribute of panel data (see, for example, Kennedy, 2003). Moreover, an unfavourable Hausman test meant that we could not be confident that the composite error was uncorrelated with the explanatory variables (thereby indicating that random-effects regression was inadvisable $)^{4}$. Thus, fixed-effects regression was the best empirical method available to investigate the four years of available data across the 152 NSW local authorities.

Explanatory variables employed (number of mining, business, farm and residential assessments) are justified on the basis that local authorities provide different services which generally reflect the different rating categories employed for NSW local governments. For example, business assessments might be associated with specific expenditures, such as economic development, safety and hygiene inspections, and street-scaping, whilst farm assessments are generally associated with both limited services, typically implying no garbage collection, water or sewerage, and a low quality of services, often including unsealed roads. In this paper, our principal

${ }^{4}$ Indeed, the fixed effects estimator (unlike random effects which is only reasonable for a limited number of cases) is always a reasonable thing to do 'for regardless of the truth of the null [Hausman test], the fixed effects estimator is unbiased because it includes dummies for the different intercepts' (Kennedy, 2003, p. 312). 
focus falls on the association between mining assessments and local government expenditure. It has long been postulated that mining enterprises place a heavy additional burden on physical infrastructure, especially airports, water, sewerage, roads, as well as social infrastructure, including health, policing, recreation and welfare (McKenzie, 2013; Miller, van Megen and Buys, 2012). However, to date, there has been no statistically significant demonstration as to whether there is a direct burden imposed on local government operational expenditure as a result of the number of mining enterprises operated in a given LGA ceteris paribus.

To ensure that we identify the burden specifically associated with the number of mining enterprises operating in a given LGA it is important that we control for variables known - from the scholarly literature - to affect local government expenditure. For instance, it widely recognised that the socio-economic status of residents is associated with the quantity and quality of local government goods and services demanded (see, for example, Drew and Dollery, 2016; Holcombe and Williams, 2009). Accordingly, we control for average wage of residents living in the LGA, the proportion of residents receiving a disability support pension and the proportion of residents receiving Newstart Allowance (welfare provided for unemployed persons of working age). We also control for the proportion of persons over the age of 65 (currently the age at which Australians become eligible for the Aged Pension) and children under the age of 15 (who are generally financial dependents). Both of these variables are routinely included as controls in regressions of local government expenditure because different age cohorts tend to demand and use different services (for instance, playgrounds and libraries for school-aged children, and Home-care and Aged-care for retirees (see, for example, Drew and Dollery, 2014a)). Population density is also controlled for in light of the fact that there is significant evidence that population density is negatively associated with the cost of providing local government services - that is the cost of some services, particularly services to property such as rubbish collection is likely to be inversely proportional to the distance travelled by rubbish trucks between properties (Drew and Dollery, 2015a). In addition, we also controlled for demographic variables attested to in the scholarly literature (proportion of Aboriginal and Torres Strait Islanders and proportion of persons who speak a language other than English at home - many local governments provide interpreters and other targeted services (such as art and culture centres, or remedial health programs) to these demographics). Our final controls employed length of council maintained roads (disaggregate to sealed (generally bitumen) and unsealed (generally graded dirt)) given that road construction and maintenance is the single largest expenditure item for councils in Australia (Drew and Dollery, 2014b). Indeed, the NSW Local Government Grant Commission (NSWLGGC, 2016, p. 42) reports that the average cost per kilometre to maintain a rural sealed road is $\$ 5,217.40$ whilst the cost to maintain an unsealed road is less than 
half of this amount $(\$ 2,047.38)$. For a recent comprehensive introduction to Local Government expenditure determinants see (Grant and Drew, 2017).

To provide further assurance we tested a number of regressions, employing additional controls, interaction terms and higher order terms. In particular it is important to note that regressions employing second-order assessment terms - which provide for the possibility of economies of scale in local government service provision - did not result in outputs with higher explanatory value (nor was the statistical significance or size of the coefficient markedly different). Thus, we do not report on regressions employing higher-order terms in the paper. This result is consistent with the evidence relating to economies of scale in Australian local government service provision which is mixed and inconclusive at best. For example, Fahey, Drew and Dollery (2016) provide a review of the empirical literature and produce econometric evidence which suggests that economies of scale are restricted to as few as three of the eleven common expenditure categories in NSW local government. We also replicated our fix-effects regressions employing an alternate regressand - expenditure per assessment - and found that the statistical significance of the regressor of interest was unchanged and the coefficient was only slightly altered.

\section{Results}

Table 4 summarises the results of three fixed-effects regressions conducted according to the empirical methodology detailed in section 3 of this paper (all appropriate tests were conducted on the model and alternate specifications were trialled to ensure robustness). In the first regression (Model 1) we tested the association for all 152 NSW local governments over the period 2011-12 to 2014-15 inclusive. It is noteworthy that only one class of assessments - mining assessments - had a statistically significant association. The results suggest that, holding all other regressors constant, a ten percent increase in the number of mining assessments is associated with an additional $0.208 \%$ expenditure per capita.

Table 4: Additional Per Capita Council Expenditure Associated with Mining Activity, 2011-12 to 201415 (see appendix for details of all regressors)

\begin{tabular}{llll}
\hline & Model 1: & Model 2: & Model 3: \\
& Per Capita Expenditure & Per Capita Expenditure & Per Capita Expenditure \\
& $($ In) - Entire State & $($ In) - Outside Sydney & (In) - Councils with \\
& & Metropolitan Area & Mining Activity \\
\hline No. Mining Assessments & $0.0208+$ & $0.0214+$ & $0.0289^{* *}$
\end{tabular}




\begin{tabular}{llll}
\hline (In) & $(0.0118)$ & $(0.0131)$ & $(0.0098)$ \\
No. Business & 0.0648 & 0.0749 & 0.0941 \\
Assessments (In) & $(0.1125)$ & $(0.1518)$ & $(0.3044)$ \\
No. Farm Assessments & 0.2403 & 0.2179 & 0.0790 \\
& $(0.1518)$ & $(0.1746)$ & $(0.2026)$ \\
No. Residential & -0.0300 & -0.0889 & 0.8811 \\
Assessments (In) & $(0.2475)$ & $(0.2904)$ & $(0.8570)$ \\
Controls & Yes & Yes & Yes \\
\hline Coefficient of & 0.7483 & 0.6917 & 0.8237 \\
Determination & & 115 & 42 \\
\hline $\mathbf{N}$ & 152 & 0.0360 & 0.0010 \\
\hline Prob>F & 0.0002 & & \\
\hline
\end{tabular}

Notes: Standard errors in parentheses. Significance levels: $+p<0.10,{ }^{*} p<0.05,{ }^{* *} p<0.01$.

It could be argued that the results are confounded by the inclusion of Greater Sydney metropolitan councils, which do not host mining enterprises and typically provide a different mix and quality of services. For instance, Greater Sydney councils do not provide water or sewerage which is delivered instead through Sydney Water. Similarly, bridges, road surfaces, curbs, footpaths, and the like are generally provided at a higher quality than in many regional and rural areas. However, when we excluded Greater Sydney councils, the level of significance remained the same (at the $10 \%$ level of statistical significance) and the size of the coefficient increased marginally: holding all other regressors constant, a ten percent increase in the numbers of mining assessments was now associated with a $0.214 \%$ increase in expenditure per capita (see Table 4, Model 2).

In addition, it is worth stressing that there was no statistically significant association with other types of local government rating assessments. This furnishes strong empirical evidence that the presence of mining enterprises within local government areas outside of the Greater Sydney area does involve a statistically significant additional operational expenditure burden (in per capita terms). Extrapolating from this evidence, it is clear that a proposal to establish a mining enterprise in a local government area involves a direct and ongoing cost for the council in question. By way of contrast, there is no empirical evidence to suggest that establishing alternate commercial enterprises, such as retail outlets or agricultural ventures, might be associated with similar ongoing increases in operational expenditure. 
To clarify the expenditure implications faced by councils where a new mine has been approved, we conducted a third stratification consisting only of councils which have issued mining assessment notices over the period 2011-12 to 2014-15 inclusive. In this last regression, reported in Table 4 under Model 3, both the size and the statistical significance of the association increased markedly. In particular, we found that a ten percent increase to the number of mining assessments was associated - at the $1 \%$ level of statistical significance - with a $0.289 \%$ increase to per capita operational expenditure, ceteris paribus. Interpreting this association one should remain mindful of the fact that the typical population size and per capita operational expenditure for New South Wales councils hosting mining enterprises (as evidenced by the median ${ }^{5}$ ) was 13,534 persons and $\$ 1,710$ respectively. One should also be cognisant of the relatively low numbers of extant mining assessments, with the median number of mining assessments at 4 , and the fact that this is ongoing additional operating expenditure. Moreover, the median value of mining assessments issued by local authorities over the period 2011-12 to 2014-15 was just $\$ 38,500$. Indeed, it might be added that there is a great deal of variation in the size of the mining assessments issued, as evidenced by a wide interquartile range of $\$ 144,739$. This suggests that, in many cases, the revenue received by a local council from mining enterprises does not cover the ongoing operational expenditure associated with the mine.

However, it would be fallacious to surmise that the mining industry is not paying its fair share of taxation. Table 5 details the quantum of royalties paid to the NSW Government for the five financial years (2011-12 to 2015-16 inclusive) and contrasts this with the tax paid to local government. For the five financial years ending 2015-16, the NSW Government received an average of $\$ 1.3$ billion dollars in royalties, whilst for the same period the average local government taxation (aggregated for all councils) was a mere $\$ 29$ million. Put differently, local councils received just over two percent of the total quantum paid out by mining companies to the NSW Government. These disparities are compounded by the fact that the NSW Government assigns the royalty payments to consolidated revenue (NSW Department of Industry: Resources \& Energy, 2017b). Thus, it is unlikely - in the absence of a programme which provides different levels of funding for rural communities which host mining enterprises - that the bulk of the royalties paid by mining companies are repatriated specifically to the communities with the purpose of providing a Coasian compensation for the costs and other negative externalities attested to in the literature (see, for example: Chapman, Tonts and Plummer, (2014), Franks, Brereton and Moran, (2014) and Miller, van Megen

\footnotetext{
${ }^{5}$ Given the skewed distribution of council size and value of mining assessments issued the median is the most appropriate measure of central tendency.
} 
and Buys, (2012)). Indeed the NSW Local Government Grant Commission standardised expenditure allowances do not have a specific category for mining and mining is only mentioned in passing as one of a number of items under the category of Planning and Building services (which has an allowance of just $\$ 30.02$ per unit of production which pales in comparison to other allowances such as road maintenance which as we have noted above runs into thousands of dollars per kilometre) ${ }^{6}$.

\footnotetext{
${ }^{6}$ Moreover, the money being allocated by the NSWLGGC is sourced from the federal government,
} not the state government. 
Table 5: Taxation Take NSW State and Local Government, 2011-12 to 2015-16 financial years ('\$m; proportion of take in parentheses)

\begin{tabular}{llll}
\hline Year & NSW State Royalty Take & $\begin{array}{l}\text { NSW Council Taxation } \\
\text { Take }\end{array}$ & $\begin{array}{l}\text { Total Royalty and } \\
\text { Local Government } \\
\text { Taxation Take }\end{array}$ \\
\hline $\mathbf{2 0 1 1 - 1 2}$ & $\$ 1,464.40$ & $\$ 24.848$ & $\$ 1,489.25$ \\
$(98.33 \%)$ & $(1.67 \%)$ & \\
$\mathbf{2 0 1 2 - 1 3}$ & $\$ 1,318.45$ & $\$ 28.45996$ & $\$ 1,346.91$ \\
& $(97.89 \%)$ & $(2.11 \%)$ & \\
$\mathbf{2 0 1 3 - 1 4}$ & $\$ 1,321.25$ & $\$ 29.90291$ & $\$ 1,351.15$ \\
& $(97.79 \%)$ & $(2.21 \%)$ & \\
$\mathbf{2 0 1 4 - 1 5}$ & $\$ 1,274.36$ & $\$ 31.748$ & $\$ 1,306.11$ \\
& $(97.57 \%)$ & $(2.43 \%)$ & \\
$\mathbf{2 0 1 5 - 1 6}$ & $\$ 1,186.89$ & $\$ 32.185$ & $\$ 1,219.08$ \\
& $(97.36 \%)$ & $(2.64 \%)$ & \\
& & & \\
& & &
\end{tabular}

Source: NSW Department of Industry: Resources \& Energy (2017b) and the audited financial statements of New South Wales local governments.

Moreover, it is by no means certain that the municipal rates paid by mining enterprises actually contribute additional revenue to affected local councils. This is due to the fact that the NSW Government has imposed local government property tax limitations in the form of an annual 'ratepeg' since 1978 (Drew and Dollery, 2015b). It serves to impose a statutory ceiling on the increase to total local government rates revenue, which is set according to the 'rate peg' determined annually by the Independent Pricing and Regulatory Tribunal of New South Wales (IPART). The rate cap is typically low, often below the Consumer Price Index (CPI), and intended to reflect the local government cost index. For instance, the rate peg for the 2014-15 financial year was set at $2.3 \%$ (IPART, 2017). Thus, when an additional mining enterprise commences operations in a given local government area, the rates paid by the mine generally do not contribute additional revenue for the local government entity, but rather reduce the change in impost on other ratepayers. The only exception occurs where a local council applies to vary the total taxation take above the specified peg under a Special Rate Variation (SRV) application to IPART.

SRV must be approved by IPART and may only be granted for periods of up to seven years. This means that councils seeking additional rate revenues to offset the added ongoing operational 
expenditure associated with the establishment of mines would need to overcome regulatory hurdles on a (maximum) seven-year cycle. In order to have an SRV approved, it is necessary for a council to demonstrate community awareness of the SRV application, provide evidence that there is a need for the increase, demonstrate that the impact on ratepayers is reasonable, provide evidence of a sustainable financing strategy and prove a 'history of well-documented council productivity improvements' (IPART, 2017). Lodging an SRV application is thus far from a foregone conclusion, especially given that the mining industry might raise strong objections that a given SRV application would not have a reasonable impact on a particular class of ratepayers (mines). Indeed, of the six councils which had an increase in the number of mining assessments issued between 2011-12 and 2012-13, only Wingecarribee Shire applied for a SRV for the 2013-14 financial year, which was approved by IPART, and none of these councils applied for a SRV for the 2014-15 financial year ${ }^{7}$. It thus seems that - in most instances - the establishment of a mine in a given LGA does not result in additional rates revenue for the council hosting the enterprise.

NSW local authorities are placed in invidious circumstances whereby they are faced with ongoing additional operating expenditure directly associated with mining operations, but are prevented by NSW Government regulation from levying enduring additional rates to recoup at least some of the extra impost. As we can see from Table 5, the NSW Government simultaneously collects some 44 times the revenue derived from mining enterprises than local councils in NSW. However, royalties collected by the NSW Government are lumped into consolidated revenue, the bulk of which is spent in non-mining regions. These financial arrangements can hardly be described as equitable for mining companies, local communities and local authorities which host mining enterprises.

\section{Policy Implications}

The empirical analysis presented in this paper has demonstrated that mining operations in local government areas in NSW place a significant additional operational expenditure burden (in the order of $0.289 \%$ per capita for each ten percent increase to the number of mining enterprises) (see Model 3 above) on local authorities in these areas and their local residents in per capita terms. Moreover, the establishment of a mine in a given LGA involves a direct and continuing cost on councils. While

\footnotetext{
${ }^{7}$ We did not track the SRV applications through to the third year following issue of additional mine assessments because the year in question was subject to an extraordinary high volume of applications arising from conditions set by the state government as part of its Fit for the Future council amalgamation program.
} 
mining companies operating in NSW contribute substantial revenues by way of royalties to the NSW Government, only a small proportion of these funds is expended in those LGAs in which mines operate. This situation appears prima facie reasonable when one considers that many state services - such as health, education and policing - are delivered directly to persons. Thus one would anticipate that per capita expenditure by the NSW Government would fall largely in urban areas where the majority of the population reside. However, the situation appears far less reasonable if one reflects on the fact that the royalty revenue arising from mining is being effectively decoupled from the costs associated with mining. Put differently, one tier of government (i.e. the NSW state government) collects revenue from an economic activity, but it is another tier of government (i.e. NSW local government) which bears the (uncompensated) costs associated with the impact of mining in the local areas where it occurs. Moreover, there is some evidence to suggest that need is greater in rural and remote areas, than it might be for urban centres. For instance, $97.7 \%$ of urban local government roads are sealed, yet just $26.5 \%$ of rural and remote local government roads are sealed (the remainder are graded dirt). In a similar vein, many residents in rural and remote areas do not have access to sewer or mains water. Thus, quite apart from the matter of compensating councils for the costs associated with hosting mining activity, there would appear to be an argument for directing additional revenue (particularly mining revenue) to rural and remote communities to address need (specifically infrastructure shortfalls).

We contend that two broad public policy solutions suggest themselves. In the first place, the NSW Government could reconsider its rate-capping policy which limits the capacity of local councils affected by mining operations to recoup the costs imposed on them by mining. Three alternative policy approaches appear feasible: (a) the NSW Government could simply dismantle its rate-pegging regime (which would affect all ratepayers in all NSW LGAs and not simply mining companies or mining LGAs) or at least exempt local authorities with mining operations in the LGAs from ratecapping (which would only affect ratepayers in LGAs which have mining operations); (b) mining rates could be explicitly excluded from the rate-peg (which would only affect mining ratepayers in LGAs which host mines); or (c) a new SRV regime could be imposed directed at recovering costs from the mining companies themselves (which once again would only affect mining ratepayers in LGAs hosting mines). However, it is evident that (a) has the potential to create further inequity for all ratepayers (particularly those located in LGAs with mining operations), whilst (b) and (c) would result in higher imposts on mining companies which already pay significant royalties to the NSW Government (thus suggesting the problem of double taxing). Equity considerations thus suggest that if (b) or (c) were introduced, then mining companies should be able to offset local government property taxation against their aggregate royalty liabilities (to mitigate the potential for double 
taxing). This would ensure public policy intervention along the lines of (b) and (c), in particular, would not disadvantage mining enterprises.

Secondly, the current NSW rate-pegging regulatory process, as well as the mining royalty regime, could be left in place and instead public policy remedies could focus on returning a calibrated proportion of mining royalties to the local authorities and local communities which host mining enterprises and accordingly bear the externalities attendant upon such mining operations. Two generic policy options suggest themselves. Firstly, a broad policy instrument could mirror the Western Australian (WA) Royalties for Regions program whereby a predetermined quantum of royalties are earmarked for regional local governments, regionally based non-government providers and regional incorporated associations (Department of Regional Development, 2017). Under the present Royalties for Regions program, $\$ 4$ billion will be expended 'over four years across regional Western Australia from 2015-16' (Department of Regional Development, 2017). A remedy of this kind would distribute funds on the basis of generalised need rather than specifically seek to compensate given LGAs in proportion to external mining costs which they have had to bear. However, it should be stressed that the efficiency and equity properties of the WA Royalties for Regions program are not fully understood, in large part because inadequate data has been made available (Mclure, 2008). Furthermore, given the fact that Royalties for Regions was essentially based on political need by the (then) WA Government to retain a coalition agreement with the National Party, as well as the proportionally much greater urbanisation of the WA population, it would be unwise to simply replicate Royalties for Regions in NSW.

A second hypothecated approach would concentrate exclusively on LGAs in which mining operations occurred. In contrast to a 'broad-brush' Royalties for Regions modus operandi, it would seek to compensate councils in accordance with the demonstrated additional costs which mining had imposed on them. This could be done by channelling funds directly from the NSW Government to the councils in question - or alternatively through the NSW Local Government Grants Commission by way of augmented grants to these local authorities. Put differently, it would attempt to place these local authorities in the circumstances in which they would have found themselves had no negative mining externalities existed.

\section{References}

Australian Bureau of Agricultural and Resource Economics and Sciences (ABARES) (2016) Australian Commodity Statistics 2016, Canberra: ABARES. 
Australian Bureau of Statistics. (2017) National Regional Profile. Canberra: ABS.

Australian Bureau of Statistics. (2016a) 6291.0.55.003 - Labour Force, Australia, Detailed, Quarterly, Nov 2016. Canberra: ABS.

www.abs.gov.au/AUSSTATS/abs@.nsf/DetailsPage/6291.0.55.003Nov\%202016?OpenDocum ent.

Australian Bureau of Statistics. (2016b) 5220.0 Australian National Accounts: State Accounts, 201516, Table 1 Gross State Product, Chain volume measures and current prices. Canberra: ABS. www.abs.gov.au/AUSSTATS/abs@.nsf/DetailsPage/5220.02015-16?OpenDocument.

Australian Capital Territory (ACT) Government. (2016) 2016-17 Budget Paper No. 3: Chapter 6 Revenue. Canberra: ACT Government.

http://apps.treasury.act.gov.au/_data/assets/pdf_file/0005/870890/Chapter-6Revenue.pdf.

Battellino, R. (2010) Mining Booms and the Australian Economy, RBA Bulletin, March: 63-69. Sydney: Reserve Bank of Australia.

Bashar, O. (2015) The trickle-down effect of the mining boom in Australia: fact or myth? Economic Record, 91 (S1): 94-108.

Blackwell, B., Dollery B. (2014) The impact of mining expenditure on remote communities in Australia: the Ranger uranium mine and the Tanami gold mine in the Northern Territory, Australasian Journal of Regional Studies, 20 (1): 68-97.

Blackwell, B., Dollery B. (2013) Resource taxation and remote Aboriginal expenditure, Economic Papers, 32 (2): 360-382.

Blackwell, B., Fischer, A., McFarlane, J., Dollery, B. (2015) Mining and other industry contributions to employment Leakage in Australia's Northern Territory, Journal of Developing Areas, 49 (6): 263-278.

Chapman, R., Tonts, M., Plummer, P. (2014) Resource development, local adjustment, and regional policy: resolving the problem of rapid growth in the Pilbara, Western Australia, Journal of Rural and Community Development, 9 (1): 72-86.

Cheshire, L., Everingham, J., Lawrence, G. (2014) Governing the impacts of mining and the impacts of mining governance: Challenges for rural and regional local governments in Australia, Journal of Rural Studies, 36: 330-339.

Common Ground. (2017) Common Ground mapping interface. Sydney: Department of Industry; Resources and Energy, (c) OpenStreetMap contributors. www.commonground.nsw.gov.au 
Cronshaw, I., Grafton, R. (2016) A tale of two states: development and regulation of coal bed methane extraction in Queensland and New South Wales, Australia', Resources Policy, 50: $253-263$

Department of Regional Development. (2017) What is Royalties for Regions? Perth: Government of Western Australia. http://www.drd.wa.gov.au/rfr/whatisrfr/Pages/default.aspx.

Downes, P., Hanslow, K., Tulip, P. (2014) The Effect of the mining boom on the Australian economy, RBA Research Discussion Paper, No. 2014-08. Sydney: Reserve Bank of Australia.

Drew, J., Dollery, B. (2014a) Keeping it in-house - households as an alternative proxy for local government output, Australian Journal of Public Administration, 73 (2): 235-246.

Drew, J., Dollery, B. (2014b) Road to ruin? Consistency, transparency and horizontal equalisation of road grant allocations in eastern mainland Australian states, Public Administration Quarterly, 39 (3): 517-545.

Drew, J., Dollery, B. (2015a) Less haste more speed: the fit for future reform program in New South Wales local government, Australian Journal of Public Administration, 75 (1): 78-88.

Drew, J., Dollery, B. (2015b) A fair go? A response to the Independent Local Government Review Panel's assessment of municipal taxation in New South Wales, Australian Tax Forum, 30 (3): 471-489.

Drew, J., Dollery, B. (2016) Does size still matter? An empirical analysis of the effectiveness of Victorian local authorities, Local Government Studies, 42 (1): 15-29.

Drew, J., Kortt, M., Dollery, B. (2014). Economies of scale and local government expenditure: Evidence from Australia, Administration \& Society, 46(6): 632-653.

Ergas, H., Harrison, M., Pincus, J. (2010), Some economics of mining taxation, Economic Papers, 29: 369-383.

Ergas, H., Pincus, J. (2014), Have mining royalties been beneficial to Australia?, Economic Papers, 33: $13-28$.

Fahey, G., Drew, J., Dollery, B. (2016) Merger myths: a functional analysis of economies of scale in New South Wales municipalities, Public Finance and Management, 16 (4): 362-382.

Fleming, D., Measham, T. (2015) Income inequality across Australian regions during the mining boom: 2001-11, Australian Geographer, 46 (2): 203-216.

Fleming, D., Measham, T., Paredes, D. (2015) Understanding the resource curse (or blessing) across national and regional scales: theory, empirical challenges and an application, Australian Journal of Agricultural and Resource Economics, 59 (4): 624-639. 
Fordham, A., Robinson, G., Blackwell B. (2017) Corporate social responsibility in resource companies - opportunities for developing positive benefits and lasting legacies, Resources Policy, 52: 366-76.

Franks, D., Brereton, D., Moran, C. (2010) Managing the cumulative impacts of coal mining on regional communities and environments in Australia, Impact Assessment and Project Appraisal, 28 (4): 299-312.

Freebairn, J. (2012) Mining booms and government budgets, Australian Journal of Agricultural and Resource Economics, 56 (2): 201-221.

Freebairn, J., (2015) Reconsidering royalty and resource rent taxes for Australian mining, Australian Journal of Agricultural and Resource Economics, 59 (4): 586-601.

Garnaut, R. (2010) Principles and practices of resource rent taxation, Australian Economic Review, 43: 347-356.

Garnett, A., Lewis, P. (2007) Population and employment changes in regional Australia, Economic Papers, 26 (1): 29-43.

Government of Western Australia. (2016) 2016-17 Budget: Economic and Fiscal Outlook, Government of Western Australia. Perth: Government of Western Australia. http://static.ourstatebudget.wa.gov.au/16-17/2016-17-wa-state-budget-bp3.pdf?

Grant, B., Drew, J. (2017) Local Government in Australia: History, Theory and Public Policy. Singapore: Springer Palgrave.

Henry, K., Harmer, J., Piggott, J., Ridout, H., Smith, G. (2010), Australia's Future Tax System: Report to the Treasurer. Canberra: Commonwealth of Australia.

Hogan, L. (2012), Non-renewable resource taxation: policy reform in Australia, Australian Journal of Agricultural and Resource Economics, 56(2), 244-259

Holcombe, R., Williams, D. (2009) “Are there economies of scale in municipal government expenditures? Public Finance and Management, 9 (3): 416-438.

Independent Pricing and Regulatory Tribunal (IPART). (2017) Special variations. https://www.ipart.nsw.gov.au/Home/Industries/Local-Government/Special-Variations.

Kennedy, P. (2003) A Guide to Econometrics - Fifth Edition. Cambridge: MIT Press.

Knop, S., Vespignani, J. (2014) The sectorial impact of commodity price shocks in Australia, Economic Modelling, 42: 257- 271.

Lacey, J., Lamont, J. (2014) Using social contract to inform social licence to operate: an application in the Australian coal seam gas industry, Journal of Cleaner Production, 84: 831-9.

Local Government Act (1993), New South Wales Consolidated Acts. http://www.austlii.edu.au/au/legis/nsw/consol_act/lga1993182/ 
Local Government Grants Commission (LGGC). (2012) NSW Local Government Grants CommissionAnnual Report 2011-12. Nowra: LGGC. https://www.olg.nsw.gov.au/commissions-andtribunals/grants-commission/grants-commission-annual-reports.

Local Government Grants Commission (LGGC). (2013) NSW Local Government Grants CommissionAnnual Report 2012-13. Nowra: LGGC. https://www.olg.nsw.gov.au/commissions-andtribunals/grants-commission/grants-commission-annual-reports.

Local Government Grants Commission (LGGC). (2014) NSW Local Government Grants CommissionAnnual Report 2013-14. Nowra: LGGC. https://www.olg.nsw.gov.au/commissions-andtribunals/grants-commission/grants-commission-annual-reports.

Local Government Grants Commission (LGGC). (2015) NSW Local Government Grants CommissionAnnual Report 2014-15. Nowra: LGGC. https://www.olg.nsw.gov.au/commissions-andtribunals/grants-commission/grants-commission-annual-reports.

Loechel, B., Hodgkinson, J., Moffat, K. (2013) Climate change adaptation in Australian mining communities: comparing mining company and local government views and activities, Climatic Change, 119 (2): 465-477.

McKenzie, F. 2013. Delivering enduring benefits from a gas development: governance and planning challenges in remote Western Australia, Australian Geographer, 44 (3): 341-358.

McKissack, A., Chang, J., Ewing, R., Rahman, J. (2008) Structural Effects of a Sustained Rise in the Terms of Trade. Canberra: Australian Treasury.

McLure, M. (2008), Royalties for Regions: accountability and sustainability, Public Policy, 3 (2): 119124.

Miller, E., van Megen, K., Buys, L. (2012) Diversification for sustainable development in rural and regional Australia: how local community leaders conceptualise the impacts and opportunities from agriculture, tourism and mining, Rural Society, 22 (1): 2-16.

NSW Department of Industry: Resources and Energy. (2017a) Who we are. Sydney: NSW Department of Industry: Resources \& Energy. www.resourcesandenergy.nsw.gov.au/regulation/aboutthe-resources-regulator/who-we-are.

NSW Department of Industry: Resources and Energy. (2017b) About Royalties. Sydney: NSW Department of Industry: Resources \& Energy. http://www.resourcesandenergy.nsw.gov.au/miners-and-explorers/enforcement/royalties.

NSW Government. (2016) Budget Statement 2016-17. Sydney: NSW Government. www.budget.nsw.gov.au.

NSW Local Government Grants Commission (NSWLGGC). (2016). NSW Local Government Grants Commission 2015-16 Annual Report. Sydney: Office of Local Government. 
NSW Minerals Council. (2013a) NSW mining history. Sydney: NSW Minerals Council. www.nswmining.com.au/industry/nsw-mining-history.

NSW Minerals Council. (2013b) Mines in NSW. Sydney: NSW Minerals Council. www.nswmining.com.au/industry/mines-in-nsw.

NSW Minerals Council. (2013c) What we mine and why we mine. Sydney: NSW Minerals Council. www.nswmining.com.au/industry/what-we-mine-why-we-mine.

NT Government. (2016) Budget Strategy and Outlook 2016-17. Darwin: NT Government. https://budget.nt.gov.au/_data/assets/pdf_file/0007/277603/BP2-2016-17-book.pdf. Office of Chief Economist. (2014) Resources and Energy Statistics 2014. Canberra: Australian Government. https://industry.gov.au/Office-of-the-ChiefEconomist/Publications/Documents/res/ResourcesEnergyStatistics2014.pdf.

Office of Local Government. (2015) Time Series Data. Office of Local Government: Nowra.

O'Kane, M. (2014) Final Report of the Independent Review of Coal Seam Gas Activities in NSW. Sydney: NSW Government, Chief Scientist and Engineer. www.chiefscientist.nsw.gov.au/_data/assets/pdf_file/0005/56912/140930-CSG-FinalReport.pdf.

Perry, M., Rowe, J. (2015) Fly-in, fly-out, drive-in, drive-out: The Australian mining boom and its impacts on the local economy, Local Economy, 30 (1): 139-148.

Petrova, S., Marinova, D. (2013) Social impacts of mining: changes within the local social landscape, Rural Society, 22 (2): 153-165.

Queensland Treasury. (2016) Budget Strategy and Oulook 2016-17. Brisbane: Queensland Treasury. https://s3-ap-southeast-2.amazonaws.com/s3-mediabudget/pdfs/budget+papers/bp2/4.\%20Revenue.pdf.

Robson, A. (2015) The Australian economy and economic policy during and after the mining boom, Economic Affairs, 35 (2): 307-316.

South Australian Government. (2016) Budget Statement. Adelaide: SA Government. http://servicesa.cdn.on.net/budget201617/pdfs/budget/2016-17_budget_statement.pdf. Tasmanian Government. (2016) The Budget 2016-2017. Hobart: Tasmanian Government. www.treasury.tas.gov.au/domino/dtf/dtf.nsf/LookupFiles/2016-17-Budget-Paper-No1.pdf/\$file/2016-17-Budget-Paper-No-1.pdf.

Victorian Government. (2016) Statement of Finances (Victorian Budget 16/17). Melbourne: Victorian Government. http://budgetfiles201617.budget.vic.gov.au/2016-17+State+Budget++BP5+Statement+of+Finances. pdf. 
Appendix

Table 4: Additional Per Capita Council Expenditure Associated with Mining Activity, 2012-2015 (all regressors)

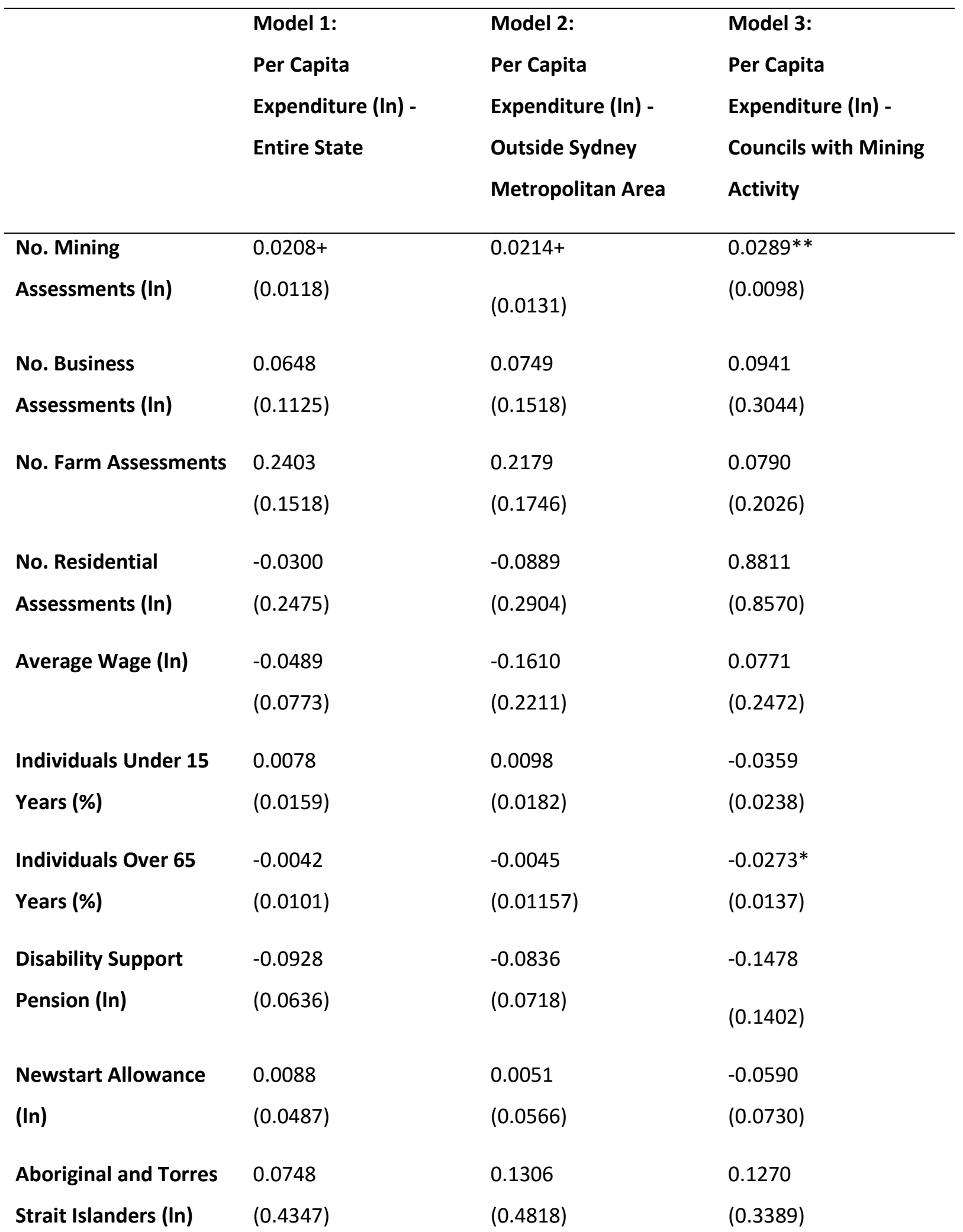




\begin{tabular}{llll} 
Sealed Roads $(\operatorname{In})$ & 0.4097 & 0.4709 & 0.5933 \\
& $(0.2569)$ & $(0.2939)$ & $(0.3621)$ \\
Unsealed Roads (In) & 0.0178 & 0.1739 & 0.0789 \\
& $(0.1177)$ & $(0.2519)$ & $(0.2675)$ \\
Population Density & $1.2709 * *$ & $1.5597^{* *}$ & $2.369 * *$ \\
(In) & $(0.3783)$ & $(0.5423)$ & $(0.7119)$ \\
\hline Coefficient of & 0.7483 & 0.6917 & 0.8237 \\
Determination & & & \\
\hline $\mathbf{n}$ & & 115 & 42 \\
\hline Prob>F & 152 & 0.0360 & 0.0010 \\
\hline
\end{tabular}

Standard errors in parentheses.

$+p<0.10, * p<0.05, * * p<0.01$. 